\title{
The Ecology of the Tropical Compound Ascidian Trididemnum solidum. III. Symbiotic Association with Unicellular Algae
}

\author{
J. Sybesma, F. C. van Duyl and R. P. M. Bak \\ Caribbean Marine Biological Institute (Carmabi), P.O. Box 2090, Curaçao, Netherlands Antilles
}

\begin{abstract}
We investigated the relation between Trididemnum solidum (Vạ Name) - a tropical compound ascidian common on the reefs of Curaçao - and its endosymbiotic unicellular algae. Colonies collected from 3 depths $(<10 \mathrm{~m}, 15-17 \mathrm{~m},>20 \mathrm{~m})$ were simultaneously analyzed for number of algae and amount of chlorophyll $\mathrm{a} \mathrm{g}^{-1}$ wet weight. Both number of algae (mean $2.78 \times 10^{6}$ cells $\mathrm{cm}^{-2}$ ) and amount of chlorophyll a (mean $150 \mu \mathrm{g} \mathrm{chl.} \mathrm{a} \mathrm{g}^{-1}$ wet weight) did not change significantly with depth. $T$ solidum tadpole larvae contained significantly higher quantities of chlorophyll a. Additional pigment analysis of samples from shallow and deep water $(<10 \mathrm{~m},>20 \mathrm{~m})$ revealed the presence of carotenes and zeaxanthin in quantities that remained the same regardless of depth, but the ratio of zeaxanthin to chlorophyll a changed significantly from 0.14 (shallow) to 0.10 (deep). Twodimentional TLC confirmed the absence of chlorophyll $b$ and $c$ in these algae. The photosynthetic $\mathrm{O}_{2}$ production of colonies from the 3 depth ranges was measured between July and September 1978 , mainly in the laboratory. We used closed systems under artificial light conditions varying from $0-240 \mu \mathrm{E} \mathrm{m}^{-2} \mathrm{~s}^{-1}(400-700 \mathrm{~nm})$. Positive production rates were measured from $40-240 \mu \mathrm{E} \mathrm{m}^{-2} \mathrm{~s}^{-1}$ (our highest experimental light level). Additional field experiments showed ascidian colonies from the shallowest sample $(<10 \mathrm{~m})$ to consume oxygen at light intensities of $600 \mu \mathrm{E} \mathrm{m} \mathrm{m}^{-2} \mathrm{~s}^{-1}$ and more. Maximum measured mean photosynthetic $\mathrm{O}_{2}$ production was $\pm 0.09 \mathrm{mg} \mathrm{O}_{2} \mathrm{~cm}^{-2} \mathrm{~h}^{-1}$ at $240 \mu \mathrm{E} \mathrm{m}^{-2} \mathrm{~s}^{-1}$ for colonies of $15-17 \mathrm{~m}$ and $>20 \mathrm{~m}$. This $\mathrm{O}_{2}$ production was significantly higher than the mean maximum production of colonies from $10 \mathrm{~m}\left(0.04 \mathrm{mg} \mathrm{O}_{2} \mathrm{~cm}^{-2} \mathrm{~h}^{-1}\right)$.
\end{abstract}

\section{INTRODUCTION}

Symbiosis between algae and invertebrates is a very common phenomenon (Buchner, 1953; Droop, 1963; McLaughlin and Zahl, 1966; Taylor, 1973; Trench, 1979). In the marine environment such relations, especially between algae and coelenterates, are particularly abundant in tropical shallow water. The association between 'zooxanthellae' and Scleractinia is a striking example of the importance of the algae for the invertebrate host in calcification and energy budget (e.g. Muscatine, 1973; Buddemeier and Kinzie, 1976; Muscatine and Porter, 1977).

Algal cells are known to occur in the test of ascidians from the Indo-Pacific (Michaelsen, 1920; Smith, 1935). Eldridge (1966), reviewing the didemnid ascidians of this region, also localized algae in the cloacal systems. He suggested the algae to be species specific because algae are transmitted by the larvae. Kott (1977), examining didemnids from the Great Barrier Reef
(Australia), quotes Newcomb and Pugh (1975) who recorded the algae living in cloacal systems and tests to be blue-green algae. Kott (1977) considers the association to be species specific. Such algal-ascidian symbiosis was unknown from the Atlantic Ocean until recently when Lafarque and Duclaux (1979) and Sybesma and Bak (1979) described associations between unicellular algae and didemnid ascidians from, respectively, Guadeloupe and Curaçao.

There are few quantitative data available on the significance of the relations of algae and non-coelenterate marine hosts, and virtually none on algae-ascidian relations (Millar, 1971; Withers et al., 1978). We investigated the number of algae and quantities of photosynthetic pigments present in colonies of Trididemnum solidum, as well as the photosynthetic $\mathrm{O}_{2}$ production of the algal-ascidian unit. We also report on other aspects of the biology of this compound ascidian (Bak et al., 1981; Van Duyl et al., 1981). 


\section{MATERIALS AND METHODS}

\section{Location and Quantity of Algae}

We prepared histological sections to locate the position of the algae in the colonies. Samples were preserved in Bouin's solution. To facilitate cutting of the test, which is densely packed with spicules, we treated the material with R. D. O. (decalcifier, Bethlehem Ltd). After exposure to a series of ethanol and xylol baths, sections $(10 \mu \mathrm{m})$ were stained with haematoxyline/ eosine and embedded in DePex for inspection with the stereo-microscope.

To count the numbers of algal cells we made a homogenate blending $20 \mathrm{ml}$ ascidian tissue with $80 \mathrm{ml}$ seawater. Large spicules were separated from the homogenate $(0.1 \mathrm{~mm}$ mesh filter). Algal cells were counted in aliguots of this homogenate with a haemocytometer (Fuchs-Rosenthal, Hotheim/Taunus). To convert number of algae to colony surface area, a conversion factor was calculated.

All samples used were from colonies collected by SCUBA diving at the southwest coast of Curaçao (Carmabi Reef Buoy, 0 and 4). The colonies were grouped for 3 depth ranges: shallow reef $(<10 \mathrm{~m})$, medium depth $(15-17 \mathrm{~m})$ and deeper reef $(>20 \mathrm{~m})$. In sampling the colonies we avoided the colony margins. All samples were processed within 4 h after collection.

\section{Pigments}

Initially we determined only the quantities of chlorophyll a in Trididemnum solidum colonies from the 3 depth ranges $(<10,15-17,>20 \mathrm{~m})$. Samples of known wet weight were extracted in $90 \%$ acetone and the amount of chlorophyll a was measured spectrophotometrically following standard methods (Vollenweider, 1967). These procedures were repeated with known numbers and wet weights of Trididemnum solidum larvae. The larvae were gathered using a larvae collector (Van Duyl et al., 1981) at a depth of $18 \mathrm{~m}$, except for 2 samples which consisted of larvae from various depths.

In addition, samples from the shallowest and deepest part of the range of Trididemnum solidum $1<10 \mathrm{~m}$, $>20 \mathrm{~m}$ ) were tested for the presence of other chlorophylls using two-dimensional Thin Layer Chromatography (Jeffrey, 1968, 1974) These samples were also analysed with High Performance Liquid Chromatography (Abaychi and Riley, 1979) to determine the quantities of chlorophylls, chlorophyll degradation products and carotenoids per unit ascidian surface area.

\section{Oxygen Production}

We used colonies from the 3 depth ranges which were carefully detached from their natural substrata. Specimens were transported submerged in seawater to the laboratory and kept in running seawater, in the dark, for $1-2 \mathrm{~h}$ before starting an experiment. To measure oxygen consumption and production the colonies were subsequently placed in an incubator (described in Vooren, in press) to be exposed to a given lightintensity for a given time (incubation time). Our light source in the laboratory was a series of flood lights (Philips PAR 38); experimental light intensities varied from 0 to a maximum of $240 \mu \mathrm{E} \mathrm{m}^{-2} \mathrm{~s}^{-1}$ at $400-700 \mathrm{~nm}$. the range of photosynthetically active radiation (LI-185 quantum-meter, LI-COR Ltd). Each colony was used in a series of $1 \mathrm{~h}$ incubations at different light intensities. Because higher light intensities than $240 \mu \mathrm{E} \mathrm{m}^{-2} \mathrm{~s}^{-1}$ are reached at depths $<10 \mathrm{~m}$ we exposed colonies of our shallow water sample, using the incubator, to such intensities on the reef at a depth of $4 \mathrm{~m}$. In all experiments temperatures were at the same level as open seawater $\left(27^{\circ}-29^{\circ} \mathrm{C}\right)$

Water movement inside the closed incubator was maintained by a magnetic stirrer. The change in the amount of dissolved oxygen was measured as a parameter of consumption or production of organic carbon. Dissolved oxygen was determined by Winkler titration (Lind, 1974).

\section{RESULTS}

\section{Algae and Algal Pigments}

Examination of microscopic slides of Trididemnum solidum showed unicellular algae to be abundant in the test tissue (Fig. 1). These algae are spherical, $7-10 \mu \mathrm{m}$ in diameter and greenish coloured in fresh condition. The number of algal. cells per unit colony surface ranged from $1.0 \times 10^{6}$ to $4.4 \times 10^{6}$ per $\mathrm{cm}^{2}$ (Table 1). We found no significant change in quantities of algae between the 3 depths (one way Anova, p $>0.75)$.

The amount of chlorophyll $\mathrm{a} \mathrm{g}^{-1}$ wet weight ranged from 45.5-302.4 $\mu \mathrm{g}$ (Table 1) There was no significant variation with depth (one way Anova, $p>0.75$ ) Eecause algal counts and chlorophyll determinations were performed with samples of the same colony, we could calculate the mean quantity of chlorophyll a per algal cell in a colony wet weight was converted to surface area and it appeared that the chlorophyll a content of the algal cells ranged from $5.7 \times 10^{-6}$ to $31.2 \times 10^{-6}$ (Table 1 )

Analysis of the amount of chlorophyll $\mathrm{a}^{-1}$ wet 


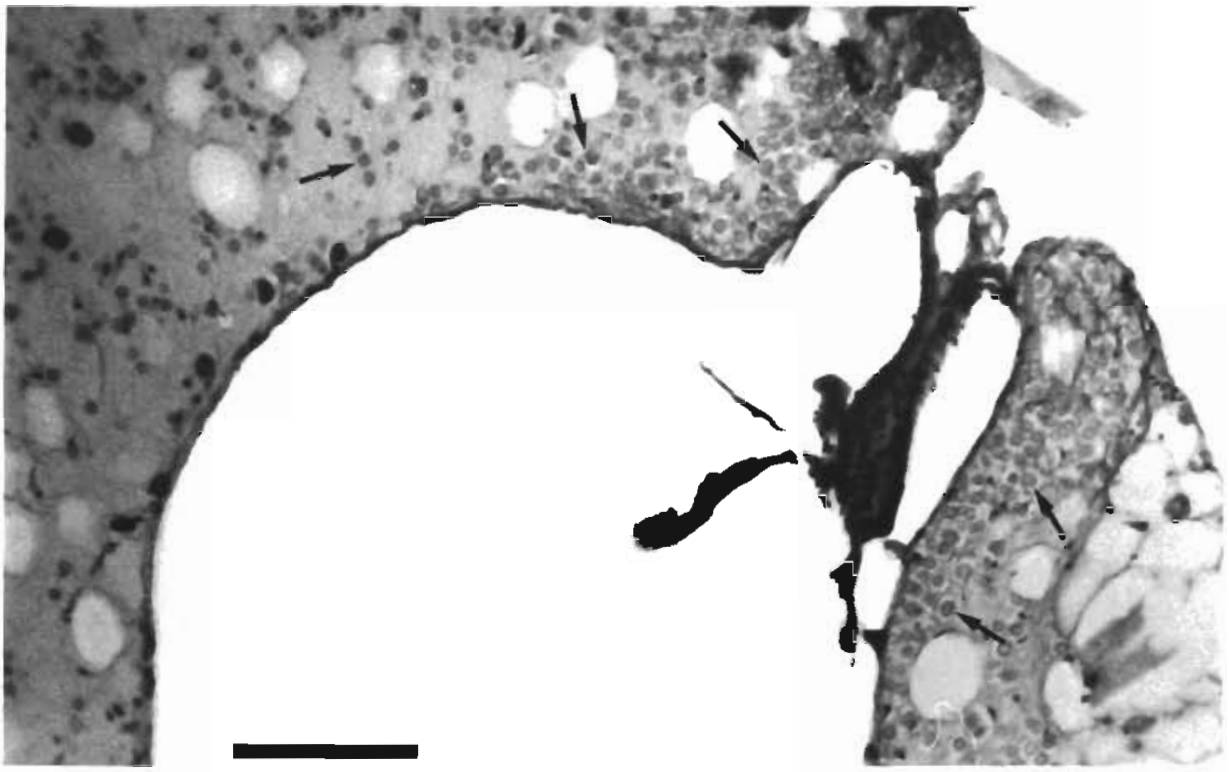

Fig. 1 Trididemnum solidum. Section showing empty cavity with remnant of zoold and surrounding test. Colony surface at upper right. Arrows indicate algal cells in test tissue. Bar $=100 \mathrm{um}$

Table 1. Mean densities of algae and quantities of photopıgments ( \pm SD) in Trididemnum solidum samples from various depths ( $\mathrm{n}$ in parentheses). There is no significant difference between the various depths (one way Anova)

\begin{tabular}{|c|c|c|c|}
\hline \multirow[t]{2}{*}{ Parameter } & \multicolumn{3}{|c|}{ Depth $(\mathrm{m})$} \\
\hline & $<10$ & $15-17$ & $>20$ \\
\hline Density of algae (cells $\mathrm{cm}^{2} \times 10^{6}$ ) & $2.7 \pm 1.6(6)$ & $2.7 \pm 1.2(6)$ & $2.9 \pm 0.9(6)$ \\
\hline Chlorophyll a (ug $\mathrm{g}^{-1}$ wet weight) & $133.2 \pm 86.6(6)$ & $165.9 \pm 85.7(6)$ & $151.1 \pm 60.3(6)$ \\
\hline Chlorophyll a $\left(\mu \mathrm{g} \mathrm{cell} \mathrm{H}^{-1} \times 10^{\circ}\right)$ & $16.1 \pm 8.8(6)$ & $18.3 \pm 8.8(6)$ & $15.7 \pm 8.6(6)$ \\
\hline Chlorophyll a $\left(\mu \mathrm{cm}^{-2}\right)$ & $24.1 \pm 6.8(4)$ & - & $27.9 \pm 4.1(4)$ \\
\hline Phaeophytin a (ug $\left.\mathrm{cm}^{-2}\right)$ & $21.4 \pm 4.5(4)$ & - & $20.4 \pm 4.8(4)$ \\
\hline Carotene $\left(u g \mathrm{~cm}^{-2}\right)$ & $5.4 \pm 1.4(4)$ & - & $5.8 \pm 1.3(4)$ \\
\hline Zeaxanthin ( $\left.\mathrm{\mu g} \mathrm{cm}^{2}\right)$ & $3.3 \pm 0.8(4)$ & - & $2.8 \pm 0.6(4)$ \\
\hline
\end{tabular}

weight in Trididemnum solidum larvae showed this to be much higher than in $T$. solidum colonies (Table 2).

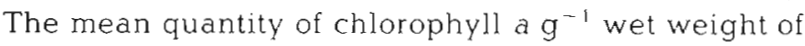
larvae was $607.06 \mu \mathrm{g} \mathrm{g}^{-1}$ wet weight trange 330.92-952.64) The comparable, significantly lower values for the colonies with a mean $150.06 \mathrm{~g}^{-1}$ wet weight are not even overlapping

Neither TLC nor HPLC analysis revealed the presence of other chlorophylls. Such absence of chlorophyll $b$ and $c$ is characteristic for blue-green algae. That the symbionts belong to the Cyanophyceae is confirmed by E. M. photographs (courtesy Dr. A. Svoboda) which showed the algae to be prokaryotic. The quantities of chlorophyll a degradation product and carotenoids present in our samples are shown in Table 1. There is no significant difference in pigment quantities with depth. However, the ratio of zeaxanthin to chlorophyll a was significantly higher (student's
Table 2. Trididemnum solidum. Chlorophyll $\mathrm{ag}^{-1}$ wet weight of larvae and chlorophyll a per larva (mean values). The mean number of algal cells per larva in a sample was calculated assuming the chlorophyll a content per cell to be similar in larvae and larger colonies. All samples were collected at 18 $m$, except those marked with asterisks which are from various depths

\begin{tabular}{|c|c|c|c|}
\hline & $\begin{array}{l}\text { Chlorophyll a } \\
\text { (Hg g }{ }^{-1} \\
\text { wet weight) }\end{array}$ & $\begin{array}{c}\text { Chlorophyll a } \\
\text { !h larva' }\end{array}$ & $\begin{array}{c}\text { Algal cells } \\
\text { larva }\end{array}$ \\
\hline & $932.64^{\circ}$ & $0.324^{-}$ & $19401^{-}$ \\
\hline & $662.22^{+}$ & $0.243^{+}$ & $14551^{+}$ \\
\hline & 859.55 & 0.253 & 15150 \\
\hline & 330.92 & 0.149 & 8922 \\
\hline & 459.54 & 0.315 & 18862 \\
\hline & 530.78 & 0.303 & 18144 \\
\hline & 473.76 & 0.317 & 18982 \\
\hline Total mea & an 607.06 & 0.272 & 16287 \\
\hline
\end{tabular}


$t$ test $p<0.01)$ in the shallow samples $(0.14)$ than in the deep samples $(0.10)$.

\section{Oxygen Production}

The relation between $\mathrm{O}_{2}$ production and light intensities for Trididemnum solidum colonies of the 3 depths is shown in Fig. 2. A oneway Anova established that there is no difference in production levels betwen the colonies from deep and medium deep water $(p>0.25)$. However, there was a significant difference ( $p<0.001$ ) between the production at these depths $(>15 \mathrm{~m})$ and that in the shallow reef $(<10 \mathrm{~m})$.

Colonies from both deep and medium deep water appeared to reach saturation at $240 \mu \mathrm{E} \mathrm{m}^{-2} \mathrm{~s}^{-1}$. Colonies from the shallow reef, where much higher light intensities are rcached, showed photoinhibition at light levels beyond $200 \mu \mathrm{m}^{-2} \mathrm{~s}^{-1}$. This was confirmed by data obtained with the shallow water sample at

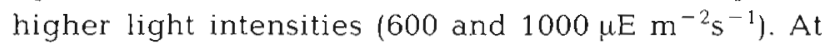
these light levels the algal-ascidian associations had a net oxygen consumption.

The ambient light levels for the different depths are shown in Fig. 3 (van Burrt, unpubl.). It appears that the ascidian colonies from the 2 lower depths (15-17 $\mathrm{m}$, $>20 \mathrm{~m}$ ), which reached their compensation point at a very low light level $\left( \pm 10 \mu \mathrm{E} \mathrm{m}^{-1} \mathrm{~s}^{-1}\right.$ ) and showed no

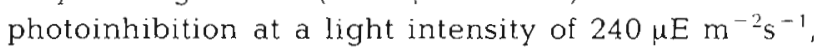
will produce oxygen for at least a considerable part of the day. In the deep reef $(25 \mathrm{~m}$ ) where light intensities never exceed the saturation level for the colonies from deeper water, oxygen production will be above compensation level for $11 \mathrm{~h}$ from 6.30 to $17.30 \mathrm{~h}$. In the

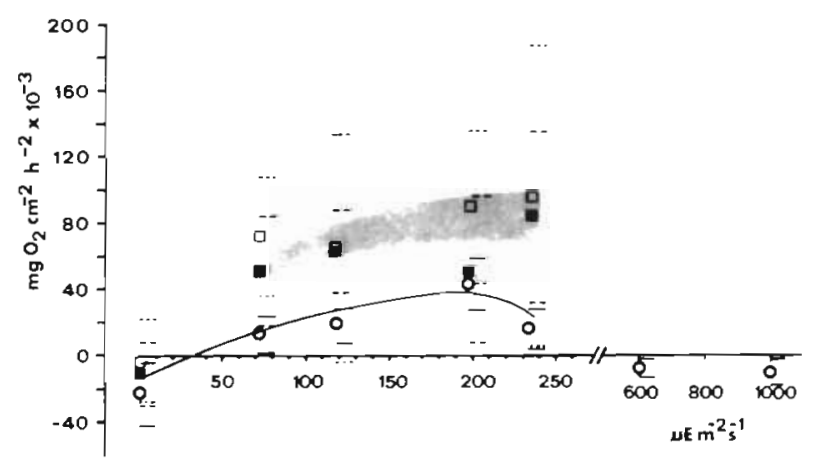

Fig. 2. Trididemnum solidum. Light/O production for colonies from 3 depths: $<10 \mathrm{~m}$ (circles), 15-17 $\mathrm{m}$ (open squares), $>20 \mathrm{~m}$ (closed squares). Sample size $\mathrm{n}=6$ for each light intensity, except 600 and $1000 \mu \mathrm{E} \mathrm{m}^{-2} \mathrm{~s}^{\prime}(\mathrm{n}=2)$. Oxygen production values for colonies of deeper water $(15-17 \mathrm{~m}$. $>20 \mathrm{~m}$ ) are significantly higher than for shallow water colonies (one way Anova, $p<0.001$ ). There is no significant difference between the medium $(15-17 \mathrm{~m})$ and deep water sample $(>20 \mathrm{~m})$. Horizontal dashes: standard deviation

$$
(-<10 \mathrm{~m},--15-17 \mathrm{~m},-->20 \mathrm{~m})
$$

shallow part of the reef $(<10 \mathrm{~m})$ where light intensities in excess of $600 \mu \mathrm{E} \mathrm{m}^{-2} \mathrm{~s}^{-1}$ occur, Trididemnum soljdum colonies will show net oxygen consumption during the middle of the day. For example, a colony at a depth of $5 \mathrm{~m}$, assuming that the algal-ascidian associa-

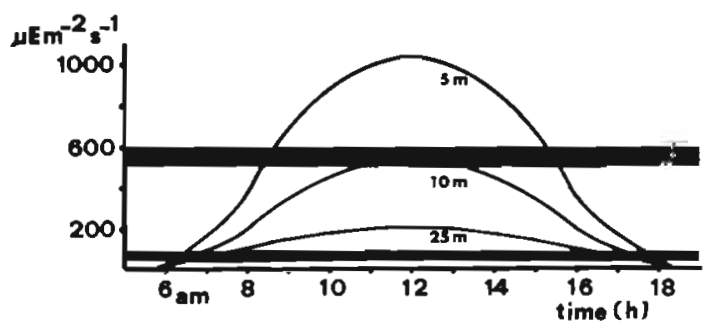

Fig. 3. Mean radiation intensities (400-700 nm) at 5, 10, and $25 \mathrm{~m}$ depth during the day (after van Buurt, unpubl.). Between the light levels indicated by horizontal bars oxygen production exceeds respiration

tion starts net oxygen consumption again at $500 \mu \mathrm{E}$ $\mathrm{m}^{-2} \mathrm{~s}^{-1}$ (Figs. 2, 3), will produce oxygen from 6.00 to $8.30 \mathrm{~h}$, and again from 15.30 to $17.40 \mathrm{~h}$. This means that the total time of net oxygen production is only half as long at this depth as it is in colonies at e.g. $25 \mathrm{~m}$ depth.

\section{DISCUSSION}

The extensive literature on symbiosis of algae with marine invertebrates appears to emphasize problems of translocation and conservation of nutrients, aspects of cell biology, etc. Data on densities of symbiotic algae, quantities of chlorophyll and the variation of these parameters in different habitats (depths) are scarce. Nevertheless, there is high consistency in the available values, varying with few exceptions from $1-8$ $\times 10^{6}$ cells $\mathrm{cm}^{-2}$ (Drew, 1972; Dustan, 1975; Stiévenart, 1975). These values stem from alcyonarian and scleractinian corals, but algal densities in Trididemnum solidum, 1.02-4.43 $\times 10^{6}$ cells $\mathrm{cm}^{-2}$, and clionid sponges (Elema, unpubl.) are of the same magnitude. Drew explained the small variation between his samples $\left(0.90-2.40 \times 10^{6}\right.$ cells $\left.\mathrm{cm}^{-2}\right)$ suggesting 2 layers of algal cells as the upper limit tolerated by the coral association. The rather larger variation in the data of Dustan, 1.93-11.80 × $10^{6}$ cells $\mathrm{cm}^{-2}$, all data of one species, Montastrea annularis (Ellis and Solander), shows at least this symbiotic association to be much more adjustable to algal densities. In $T$. solidum the algal densities cannot be influenced, as may be the case in scleractinian corals, by variation in the calyx and polypary structure. It is conceivable that the comparatively simple, essentially 
two-dimensional structureless surface of the ascidian colonies is the reason the values on algal density are in the lower part of the range of published data. The overall similarity in rumber of algal symbionts per unit surface area in marine invertebrates suggests an underlying principle which is yet to be explained.

Variation of densities of symbionts with depth (light intensity) has been studied in a few scleractinian corals with confusing results. In some species algal numbers are reported not to vary with depth (Drew, 1972; Redalje, 1976), in others to decrease with depth (Stiévenart, 1975), for other species there appears to be a maximum algal density at intermediate depths (20 m: Bak et al., unpubl.) and there may be genetic differences involved between shallow and deep water populations of the coral-algal association (Dustan, 1975).

Chlorophyll quantities in scleractinian corals may or may not increase with depth. This means that sometimes there is a consistent quantity of chlorophyll present per algal cell (Bak et al., unpubl.) while other studies showed a variation (Redalje, 1976); sometimes there are differences between the deep and the shallow association. This phenomenon may be explained by the existence of differences between various forms of the algal symbiont, Gymnodinium microadriaticum Freudenthal (e.g. Schoenberg and Trench, 1980). It also remains to be examined to what degree scatter in the published data is related to microhabitat variation.

The algae in Trididemnum solidum appear to be unrelated to the coral symbionts, and it must be investigated whether similar physiological races - or possibly species - appear among the various symbionts found in didemnid ascidians. An important difference between the blue-green - ascidian and the Gymnodinium - scleractinian relation is the much higher concentration of chlorophyll a per surface area in the former (Stiévenart, 1975; this paper: Table 1). The number of algal cells per surface area is similar in both associations and the difference is caused by the much higher chlorophyll content per cell of the $T$. solidum symbionts. That this difference may be significant is supported by the results of Thinh and Griffith (1977). They found a high chlorophyll a content per algal cell, $7 \times 10^{-6} \mu \mathrm{g}$, well comparable with our range of $5.7-31.2 \times 10^{-6} \mu \mathrm{g} \mathrm{cell}{ }^{-1}$. These are much higher chlorophyll a contents than reported for coral symbionts (e.g. $1.5 \times 10^{-6} \mu \mathrm{g} \mathrm{cell}{ }^{-1}$; Stiévenart, 1975). Data on the chlorophyll a content of larvae of symbiotic associations are unknown to us. Our own data show the concentration of chlorophyll to be much higher in the larvae than in the colonies. This suggests firstly that the ascidian is highly dependant on its algal symbionts, and secondly that infection of aposymbiotic larvae is unlikely. This means that also the algae must have a close relation with their animal host, at least on the habitat level.

In spite of the similarity in algal densities and chlorophyll a concentration of Trididemnum solidum colonies over the reef, we found a significant difference in oxygen production between the shallow and deep reef colonies. Oxygen consumption in the dark was of the same magnitude in both groups. There are several possible explanations: Firstly, the significant change in zeaxanthin to chlorophyll a ratios with depth may be induced by environmental conditions such as light levels (Parson et al., 1977; Wettern and Weber, 1979); Hager and Meyer-Bertenrath (1967) mentioned zeaxanthin quantities to be positively related with light intensity; a possible function of zeaxanthin is shielding off the photopigments, and the colonies from deeper water, lacking such a filter, may have been more sensitive to our artificial light source. Secondly, the photosynthetic quotient becomes higher when non-carbohydrates are produced (Parson et al., 1977) and blue light favours protein synthesis over carbohydrate synthesis (Wallen and Green, $1971 \mathrm{a}, \mathrm{b}, \mathrm{c}$ ); the deep water colonies are possibly adapted to relatively blue light and the high oxygen production may be the result of a difference in the photosynthetic quotient. Unfortunately, it was logistically not feasible to test these alternatives and some reservation must be made in our interpretation.

Oxygen production in the ascidian symbiotic association is relatively high (maximum values of $0.04-0.09$ $\mathrm{mg} \mathrm{O}_{2} \mathrm{~cm}^{-2} \mathrm{~h}^{-1}$ ) compared with similar data on production per surface area in various algae (0.015-0.043 $\mathrm{mg} \mathrm{O}_{2} \mathrm{~cm}^{-2} \mathrm{~h}^{-1}$; e.g. Marsh, 1968; King and Schramm, 1976: Wanders, 1976).

The significant difference in oxygen production of Trididemnum solidum with depths may indicate that a large part of the energy budget is easily provided by the algal symbionts in the deeper colonies. Oxygen production as such, however, does not give any information on the efficiency or magnitude of energy translocation between alga and host. In Scleractinia it has been estimated that generally $35-40 \%$ of the algal photosynthetate is contributed to the host (Wethey and Porter, 1976 a; McCloskey et al., 1978). Wethey and Porter (1976 b) suggest that the efficiency of the translocation may vary with depth. Compound Didemnidae are filter feeders (Millar, 1971) and it is not known whether material is exchanged within the algal-ascidian association.

$P / R$ ratios give less information on the internal energy budget of symbiotic associations than is generally inferred (McCloskey et al., 1978). These authors point out that $P / R$ ratios $>1$ are required to suffice the metabolic requirements of the invertebrate-algal unit. Of course, high $\mathrm{P} / \mathrm{R}$ ratios make it more likely that the 
total metabolic demand is filled, assuming that a given percentage of photosynthetically fixed energy is translocated.

Approximate values for the $P / R$ ratio of shallow and deep reef colonies of Trididemnum solidum can be calculated using the daily length of the oxygen production period (see Results), darkness respiration values (assuming a constancy of consumption rate over the $24 \mathrm{~h}$ period, the error introduced is probably small; Mergner and Svoboda, 1977) and oxygen production levels at the different light intensities (Fig. 2). Such calculations lead to a very high $P / R$ ratio for deep reef colonies: \pm 7 , and a relatively low $P / R, 1.0$ for shallow reef colonies. The maximum $P / R$ of 7 seems exceedingly high in view of most $P / R$ values encountered in hermatypic scleractinians (McCloskey et al., 1978; their Table 1). But such maximum values, $8-8.5$, have been found in the only other study on photosynthesis in didemnid ascidians (Thinh and Griffith, 1977). These authors studied shallow water colonies which photosynthesized at saturation level at very high intensities ( $\pm 2000 \mu \mathrm{E} \mathrm{m}^{-2} \mathrm{~s}^{-i}$ ). Our shallow reef samples showed photoinhibition and net oxygen consumption at much lower light levels $\left( \pm 500 \mu \mathrm{E} \mathrm{m} \mathrm{m}^{-2} \mathrm{~s}^{-1}\right)$, while we infer highest $\mathrm{P} / \mathrm{R}$ ratios to occur in colonies from relatively deep water.

We conclude that the symbiotic association of Trididemnum solidum and blue-grenn algae is a very efficient oxygen producer and although the exact functioning of the symbiotic association over the reef slope remains obscure, alga and host are highly interdependent. There appears to be a great potential of energy translocation in the association, the magnitude of which may depend strongly on the reef habitat.

Acknowledgements. We thank Oscar Frans and Frank Isabella for diving assistance; Aubrey Tiel, Marjo v. Staveren, for assistance in the field and the laboratory. We are indebted to the Dept of Systematic Botany. University of Groningen for loan of incubators and to G. Kraaij (NIOZ, Texel) for his expertise with HPLC and TLC techniques. R. Delvoye (Utrecht) prepared the histological sections and $\mathrm{Dr} A$. Svoboda (Bochum) produced the E. M. photographs. Dr W. L. Bakhuis advised in the statistical analysis. Stimulating discussions with Dr W. Gieskes (NIOZ, Texel) and G. Kradu are gratefully acknowledged. Dr C van den Hoek (Groningen) and $\operatorname{Dr}$ R. H. Millar (Oban) kindly commented on the manuscript. The first author was supported by a grant from the Beyerinck-Popping Fund, Holland.

\section{LITERATURE CITED}

Abaychi, J. K, Riley, J. P. (1979). The determination of phytoplankton pigments by High-Performance Liquid Chromatography. Analytica chim. Acta 107: 1-11

Bak, R. P. M., Sybesma, J., Duyl, F. C., van (1981). The ecology of the tropical compound ascidian Trididemnum soljdum. II. Abundance, growth and survival. Mar. Ecol. Prog. Ser 6: 43-52

Buchner, P. (1953). Endosymbiose der Tiere und pflanzlichen Mikroorganismen, Birlihänser, Basel, Stuttgart

Buddemeier, R. W. Kinzie, R. A. (1976). Coral growth. Oceanogr. mar. Biol. A. Rev. 14: 183-225

Drew, E. A. (1972). The biology and physiology of alga invertebrate symbiosis: II. The density of symbiotic algal cells in a number of hermatypic hard corals and alcyonarians from various depths. J. exp. mar. Biol. Ecol. 9: 71-75

Droop, M. R. (1963). Algae and invertebrates in symbiosis. Symp. Soc gen. Microbiol. 13: 171-199

Dustan, P. (1975). Genecological differentiation in the reefbuilding coral Montastrea annularis. Ph. D. thesis, State University of New York, New York

Duyl, F. C., van, Bak, R. P. M., Sybesma, J. (1981). The ecology of the tropical compound ascidian Trididemnum solidum. I. Reproductive strategy and larval behaviour Mar. Ecol. Prog. Ser. 6: 35-42

Eldridge, L. C. (1966). A taxonomic review of Indo-pacific Didemnid ascidians. Micronesica 2: 161-263

Hager, A., Meyer-Bertenrath, T (1967). Die Identifizicrung der an Dünschichten getrennten Carotinoide gruner Blatter und Aigen. Planta 76: 149-168

Jeffrey, S. W. (1968). Quantitatıve thin-layer chromatography of chlorophylis and carotenoids from marine algae. Biochim. biophys. Acta 162: 271-285

Jeffrey, S. W (1974). Profiles of photosynthetic pigments in the ocean using thin-layer chromatography. Mar. Biol. 26: $101-110$

King, R. J., Schramm, W (1976). Determuation of photosynthetic rates for the marine algae Fucus vesiculosus and Laminarja digitata. Mar Biol. 37.209-213

Kott, P. (1977). Algal supporting Didemnid ascidians of the Great Barrier Reefs. In: Proceedings Third International Coral Reef Symposium, Miami, Vol. 1, pp. 616-622

Lafarque, F., Duclaux, G. (1979). Premier example, en Atlantique tropical, dune association symbiotique entre une ascidie Didemnidae et une cyanophycée chroococcale: Trididemnum cyanophorum nov. sp. et Synechocystes trididemni nov. sp. Annis inst. Oceanogr., Paris 55: $163-184$

Lind, O. T. (1974). Handbook of common methods in limnology, The C. V. Mosky Comp., St. Louis

Marsh, J. A. (1968). Prımary productıvity of the reef-building calcareous red algae, Ph. D. thesis, University of Georgia

McCloskey, L. R., Wethey, D. S. and Porter, J. W. (1978) Measurements and interpretations of photosynthesis and respiration in reef corals. In: Stoddart, D. R., Johannes, R. E. (eds.) Coral reefs: Resedrch methods. Unesco No 5, pp. 379-396

McLaughlin, J. J. A., ZahI, P. A. (1966). Endozoic algde. In Henry, S. M. (ed.) Symbıosis I. Academic Press, Now York, pp. $257-297$

Mergner, H. Svoboda, A. (1977). Productivity and seasonal changes in selected reef areas in the Gulf of Aqaba (Red Sea). Helgolander wiss. Meeresunters. 30: 383-399

Michaelsen, W. (1920). Die trikobranchen Ascidien des westJichen Indischen Ozeans: Didemniden. Mitt. zool. Mus. Hamb. 37: 1-74

Millar, R. H. (1971). The brology of ascidians. Adv. mar Biol. 9: $1-100$

Muscatine, L. (1973). Nutrition of corals. In: Jones, E. A., Endean, R. (eds.) Biology and genlogy of coral reefs II Biology I. Academic Press, New York, london, pp. 77-115

Muscatine, L., Porter, J. W (1977). Reef cuals: Blutualistic 
symbiosis adapted to nutrient-poor environments. Bioscience 27: 454-460

Newcomb, E. B., Pugh, I. D. (1975). Blue-green algae associated with ascidians of the Great Barrier reef. Nature, Lond. 253: $533-534$

Parson, I. R., Takahashi, M. Hargrave, B. (1977). Biological oceanographic processes, Pergamon Press, Oxford, New York

Redalje, R. (1976). Light adaptation strategies of hermatypic corals. Pacif. Sci. 30: 212

Schoenberg, D., Trench, R. K. (1980). Genetic variation in Symbiodinium (= Gymnodinium) microadriaticum Freudenthal, and specificity in its symbiosis with marine invertebrates. I. Isoenzyme and soluble protein patterns of axenic cultures of Symbiodonium microadriaticum. Proc. R. Soc. B 207: 405-427

Smith, H. G. (1935). On the presence of algae in certain Ascidians. Ann. Mag. nat. Hist. 15: 615-624

Stiévenart, J. (1975). Etude de l'association des zooxanthelles avec les polypes des genres Mycetophyllia et Agaricia (Jamaica). C. r. hebd. Séanc. Acad. Sci., Paris (Série D) 280: 1603-1606

Sybesma, J., Bak, R. P. M. (1979). The distribution of Trididemnum solidum (Van Name), an algae containing compound ascidian, along the coasts of Curaçao (N.A.). Proc. Assoc. Is. Mar Labs. Carib. 14:6

Taylor, D. C. (1973). The cellular interactions of algal-invertebrate symbiosis. Adv. mar Biol. 11: 1-56

Thinh, L. V., Griffith, D. J. (1977), Studies of relationship between the ascidian Diplosoma virens and its associated microscopic algae I. Photosynthetic characteristics of the algae. Aus. J. mar Freshwat. Res. 28: 673-681

Trench, R. K. (1979). The cellular interactions of algalinvertebrate symbiosis. A. Rev. Pl. Physiol. 30: 485-531

Vollenweider, R. A. (1967). A manual on methods for measur- ing primary production in aquatic environments, IBP Handbook 12, Blackwell, Oxford, Edinburgh

Vooren, C. M. (in press). Photosynthetic rates of benthic algae from the deep coral reef of Curaçao. Aquat. Bot.

Wallen, D. G., Green, G. H. (1971 a). Light quality in relation to growth, photosynthetic rates and carbon metabolism in two species of marine plankton algae. Mar. Biol. 10:34-43

Wallen, D. G., Green, G. H. (1971 b). Light quality and concentration of proteins, RNA, DNA and photosynthetic pigments in two species of marine plankton algae. Mar. Biol. 10: $44-51$

Wallen, D. G., Green, G. H. $(1971 \mathrm{c})$. The nature of the photosynthate in natural phytoplankton populations in relation to light quality. Mar Biol. 10: 157-168

Wanders, J. B. W. (1976). The role of benthic algae in the shallow reef of Curaçao (Netherlands Antilles). 1: Primary productivity in the coral reef. Aquat. Bot. 2: 235-270

Wethey, D. S., Porter, J. W. (1976 a). Sun and shade differences in productivity of reef corals. Nature, Lond. 262: 281-282

Wethey, D. S., Porter, J. W. (1976 b). Habitat-related patterns of productivity of the foliaceous reef coral, Pavona praetorta Dana. In: Mackie, G. O. (ed.) Coelenterate ecology and behaviour. Plenum Press, New York, London, pp. 59-66

Wettern, M., Weber, A. (1979). Some remarks on algal carotenoids and their interconversion into animal carotenoids. In: Hoppe, H. A., Levring, T. Tanaka, Y. (eds.) Marine algae in pharmaceutical science. Walter de Gruyter, Berlin, New York, pp. 551-568

Withers, N., Vidaver, W., Lewin, R. A. (1978). Pigment composition, photosynthesis and fine structure of a non-bluegreen prokaryotic algal symbiont (Prochloron sp.) in a didemnid ascidian from Hawaiian waters. Phycologia 17: $167-171$ 